\title{
Does Audit Quality Matters in Malaysian Public Sector Auditing?
}

\author{
Aida Hazlin Ismail ${ }^{1}$, Natasha binti Muhammad Merejok ${ }^{1}$, Muhamad Ridhuan Mat Dangi ${ }^{1} \&$ Shukriah Saad $^{1}$ \\ ${ }^{1}$ Universiti Teknologi MARA, Kampus Puncak Alam, Selangor, Malaysia \\ Corespondence: Fakulti Perakaunan, Universiti Teknologi MARA, Kampus Puncak Alam, 42300 Selangor, \\ Malaysia.
}

Received: April 20, 2019

Accepted: May 7, 2019

Online Published: May 19, 2019

doi:10.5430/ijfr.v10n3p203

URL: https://doi.org/10.5430/ijfr.v10n3p203

\begin{abstract}
Auditors play a key role in contributing to the credibility of the financial statements on which they are reporting. High-quality audits support financial stability. The responsibility for performing quality audits of financial statements rests with the auditors. However, audit quality is best achieved in an environment where there is support from and appropriate interactions among participants in the financial reporting supply chain. Most prior studies look into audit quality from the perspective of private sector however this study focus on the quality of public sector auditing in Malaysia. There are three independent variables being investigated in this study that are the auditor's independence, auditor's competency and auditor's workload. Data were collected through the distribution of questionnaires to 114 samples of auditors involved in public sector audit in Malaysia. The data were analysed using correlation test and regression test. The findings of this study show that there are positively significant relationship between auditor's independence and auditor's competency on audit quality. The results revealed that auditor's competency is the most significant factor affecting the audit quality in public sector audit. However, results show that auditor's workload has a negative and insignificant impact on audit quality. Hence, this study recommends that the audit departments to strengthen the audit quality and could improve the quality of the financial reporting in the public sector. In addition, auditor's competency should be enhanced among the auditors in public sector to ensure high quality of audit work performed. Future studies should explore other variables such as client satisfaction, auditor switching and auditor's turnover in public sector auditing.
\end{abstract}

Keywords: audit quality, auditor's independence, auditor's competency, auditor's workload, public sector audit

\section{Introduction}

Audit quality remains a misunderstood construct, a black box, despite the overabundance of research on the topic (Knechel, Krishnan, Pevzner, Shefchik, and Velury, 2013). This is particularly worrying, as according to a recent survey (KPMG 2016), the quality of external audits is among the top concerns of CEOs today. Knechel et al. (2013) further argued that audit quality is more multidimensional than previously acknowledged, and has not been operationalized with enough variables. In addition, audit quality research only concentrates on the private sector audit but not on the issues of audit quality in the public sector audit.

In Malaysia, the governing body that safeguards the conduct of public sector auditing is the National Audit Department (NAD) and it is headed by the Auditor General. The role of the NAD in ensuring public accountability in Malaysia has existed back for 100 years ago. In 1957, legislated audit was introduced when Malaysia attained her independence and the scope of government auditing was spelt out in the Audit Act 1957. Throughout this period, there have been significant developments in the audit approach to suit changing times but the audit objectives as enshrined in the Malaysian Constitution 1957 were strictly preserved. Conventionally, public sector auditing is primarily concerned with legality, reliability and integrity of government expenditure. Over the years, the audit function has expanded to include monitoring government programs and activities by paying attention to accountability, output, efficiency and value-for-money.

Since 2002, there have been significant developments in the accountability role of the Auditor General and the type of auditing emphasized by the government, from financial statements to compliance to performance auditing (Othman, Nath and Mahzan, 2013). At present, the National Audit Department is responsible for carrying out audits on all federal government ministries, departments and agencies and state governments. This includes 24 Federal ministries and 86 departments, 13 state government, 112 federal government agencies, 139 state government 
agencies, 144 local authorities and 15 Islamic religious councils. In addition, government linked companies with more than $51 \%$ of its share capital owned by the government or those that received grant from the government, are subject to be audited by the National Audit Department. Therefore, the responsibility of the National Audit Department is to audit all government agencies that pose a burden to auditors in ensuring that they meet the audit expectation gap. Hence, this has created a more challenging role of the auditors in order to keep pace with the changes with the public-sector environment (Rute, 2016; Samaila Uzochukwu \& Ishaq 2018).

The challenges faced by the auditor in the changing of public-sector environment have raised a concern about audit quality. The measurement of audit quality in public sector audit presents a significant challenge for practitioners and academicians, as there is no single model to define and operationalize the audit quality. The possibility of auditors carrying out their duties guided by Generally Accepted Auditing Standards (GAAP) and ethical codes relevant to public auditors and then findings violations in the client's accounting system during the audit process indicates audit quality (Usman et al., 2014; Senathip Mujtaba \& Cavico 2017). Tan Sri Ambrin Buang, the former Auditor General of Malaysia has expressed his hope for greater autonomy accorded to the National Audit Department. Empirical studies have revealed that the competency and independence of auditors influence the quality of auditing (Suyono, 2002; Irmawan, Hudaib and Haniffa, 2013; Octavia and Widodo, 2015; Bouhawia, Irianto and Baridwa, 2015; Sulanjaku and Shngjergji, 2015; Njoroge, 2016 and Asmara, 2016). Besides the auditor's competency and independence, the auditor's workload has also been a concern in the auditing profession. The resource constraint will lead to work overload for auditors as they are expected to accomplish the workload that exceeds their capabilities during the given period (Mohd Nor, 2011). This indicates that limited resources are one of the factors that affect the success of government audit (Ahmad, Othman and Jusoff, 2009 and Massod and Lodhi, 2015). Thus, this study on audit quality of public sector audit is crucial in ensuring public funds are managed wisely and public confidence toward the auditing profession is restored. It also helps public sector organizations to achieve accountability and integrity, improve operations and instill confidence among citizens and stakeholders. Furthermore, most of the studies in audit quality investigated on the private sectors with only a handful on audit quality in the public sector (Carslaw, Pippin and Mason, 2012; Setiyawati Iskandar \& Basar 2018). Moreover, none of these studies had looked into the relationship between auditor's independence, auditor's competency and auditor's workload in public sector auditing. Hence, this study intends to add to the existing corpus of knowledge regarding audit quality factors that might influence public sector auditors.

\section{Literature Review and Hypothesis Development}

\subsection{Definition of Audit Quality}

Audit quality is an important concept in both the public and private sectors, but there is no single model to define and operationalize audit quality (Phan, 2016). The audit quality is critically argued yet minimally understood and in spite of the differences in the definition, there is little agreement about how to describe audit quality (Massod and Afzal, 2016; Stavrou, 2018). The widely used definition of audit quality is the definition by DeAngelo (1981), who defined audit quality as the likelihood that an auditor will both, find a breach in the client's accounting system and report the breach. Despite the fact that there are diverse definitions of audit quality; there are generally two fundamental elements developed when evaluating the definition of quality, which are the auditor's capability to both find and declare the misstatement and the auditor's independent (Al-khaddash, Al Nawas and Ramadan, 2011; Usman, Sudarma, Habbe and Said, 2014; Sulanjaku and Shngjergji, 2015 and Octavia and Widodo, 2015). DeFond and Zhang (2013) believe that the higher the audit quality, the "greater assurance of high financial reporting quality."

The definition of audit quality could vary according to the perspective of clients, auditors, regulators and stakeholders involved in the financial reporting process (Enofe, Aderin and Ehi-oshio, 2013). The different perspectives on what constitutes audit quality will influence the type of indicators one might use to evaluate audit quality (Hosseinniakani and Mota, 2014; Octavia and Widodo, 2015; Sulanjaku and Shngjergji, 2015). The audit quality has been given considerable attention in previous literature, auditing standards and audit legislation. Despite that, there is no agreement on a single definition of audit quality as each stakeholder in financial reporting views audit quality according to their work or position (Knechel et al. 2013 and Anis 2014).

The definition of audit quality in the public sector will differ from the private sector since the public sector varies from the private sector in numerous ways, including its accounting and financial reporting. The difference of the public sector from a business organization, for instance, is the absence of a profit goal (Samelson, Lowensohn and Johnson, 2006). It is mandatory for the public sector to appoint only public sector auditors to scrutinize the public sector administration, which then creates a domination of public sector auditors (Masood and Afzal, 2016). The absence of rivalry at the public sector level hampers audit quality. However, public sector governance can be 
enhanced if the background knowledge and skills of auditors are strong (Masood and Afzal, 2016; Stübinger, Walter \& Knoll 2017).

In addition, Usman et al., (2014) indicated that the public sector audit procedure is similar to the private sector audit. The distinction is in the political influence of the nation concerned and government policy. Therefore, due to the differences, there is a requirement for an independent auditor to examine the public sector's financial position. The effectiveness of the public sector can be reflected by a quality audit. The audit includes exploring approaches as indicated by international standards and guidelines, and gives opinions, state expectations, and lends caution to related entities (Lee, Su, Tsai, Lu and Dong, 2016). The possibility of an auditor carrying out duties guided by generally accepted auditing standards and ethical codes relevant to a public accountant only to find violations occurring in the client's accounting system during the audit process, indicates audit quality (Usman et al, 2014; Supian \& Ab 2018).

\subsection{Auditor Independence}

In order to inspire confidence among the public on the reliability of financial statements, the audit quality is crucial. Hence, when an auditor is independent, the quality of audit will increase (Suyono, 2012). Moreover, Octavia and Widodo (2015) indicated that the likelihood of an auditor discovering detailed misstatements relies on auditor independence. The finding demonstrated that independence has a significant impact on audit quality. When the auditor is independent, it will bring about a decent audit quality. In addition, Sulanjaku and Shngjergji (2015) found that one of the indirect measures that severely impacted the Albanian auditor's quality was auditor independence. When the auditor's independence is low, the audit quality will also be low.

In the context of the public sector environment, the auditor's independence implies that auditors cannot be simply influenced by the public, since they work for the public's benefit. Furthermore, auditors are not defended when supporting the interests of anybody. The auditor is obliged to be transparent not exclusively to the organization's management, but also to different parties who place trust in the work of the auditor (Octavia and Widodo, 2015). The auditor's independence appears to be the factor that mostly impacts auditor's quality (Sulanjaku and Shngjergji, 2015). This means that when an auditor is independent, he/she will be able to present true and fair results to the management, which will then make the financial statement more credible and reliable.

Although most of the studies found that there is a significant relationship between auditor independence and audit quality, Al-Khaddash, Nawas and Ramadhan (2013), found that there was an insignificant relationship between auditor independence and audit quality. Moreover, Irmawan, Hudaib, Haniffa, (2013) found that from the perception of auditors and users of audit reports, they have less confidence on auditor independence in 30 situations. The finding from auditors and users indicates that auditors have lower confidence in auditor independence compared to users in situations such as crossover from audit firm to client, provision of Non-Audit Service, auditor litigation and indirect financial interest through shareholdings; meanwhile, users had low confidence on auditor independence because of individual relationships with political figures and client constraints such as a strict budget for audit fees. This study predicted that auditor independence has a relationship with the audit quality of public sector auditors. Based on the literature review the following hypothesis was proposed:

H1: There is a relationship between auditor's independence and audit quality in public sector auditors in Malaysia.

\subsection{Auditor's Competency}

Octavia and Widodo (2015) found that there was a positive and significant correlation between the competency of government auditors and the quality of financial reporting. Consequently, audit quality could be improved by having a competent auditor. Furthermore, Bouhawia, Irianto and Baridwan (2015) demonstrated that competence has a critical impact on audit quality. From the study, it was found that there is a significant and positive correlation between competence and audit quality. Additionally, Njoroge (2016) studied internal auditors in Kenya's public sector and found that the competency of internal auditors was imperative in promoting good governance and guaranteeing effective use of public resources. In association with internal auditors with high competency levels, there was a positive connection with performance, which led to a more compelling corporate administration.

Likewise, Rai (2008) mentioned that the audit function requires auditors to be skilled with a high level of expertise capability and an obligated involvement to viably execute their responsibilities. To accomplish great management, auditors more likely have attained a minimum education level and a good professional standing in auditing. This study predicts that auditor's competency has a relationship with the audit quality of government auditors. Based on the literature review the following hypothesis was proposed:

$\mathrm{H} 2$ : There is a relationship between auditor's competency and audit quality of public sector auditors in Malaysia. 


\subsection{Auditor's Workload}

Persellin et al., (2017) found that audit workload indirectly affected audit quality by reducing job satisfaction and subsequently expanding auditor withdrawal conduct. Generally, the finding showed that excessive workloads exist and these workloads might inversely affect audit quality. In addition, Lopez and Peters (2012) explored whether peak season and related workload pressure influences audit quality. The results of the regression model demonstrated that peak season organizations and work overload had weakened audit quality from 2006 to 2009. Prior experimental and survey research inquiry demonstrated that workload pressure prompted dysfunctional behaviour and lower audit quality among individual auditors.

Furthermore, Persellin, et al., (2014) supported the PCAOB's concern that excessive workloads could be an underlying factor in audit deficiencies. Meanwhile, workload can be seen as either a burden or a challenge stressor, in which the overwhelming workloads frequently associated with occupied seasons will bring out negative emotions. It can be foreseen that auditors will probably view workload as a burden stressor rather than a challenge stressor. As audit workload increases, the auditors will feel more job strain and less job satisfaction, which inevitably leads to decreased audit quality. In contrast, Mohd Nor (2011) examined whether heavy auditor workloads will influence Reduced Audit Quality Practices (RAQPs) and found that heavy workloads did not affect RAQP.

This study predicted that auditor workload would have a relationship with the audit quality of government auditors despite mix findings from the previous studies. Based on the discussion from the literature review, the following hypothesis was proposed:

H3: There is a relationship between auditor's workload and audit quality experienced by public sector auditors in Malaysia.

\subsection{Conceptual Framework}

Figure 1 represents the conceptual framework for the current study based on the Theory of Inspired Confidence, which embodies the whole picture of this study. As shown in the Figure 1, auditor's independence, auditor's competency and auditor's workload are the factors (independent variables) that influence audit quality of public sector auditors (dependent variable).

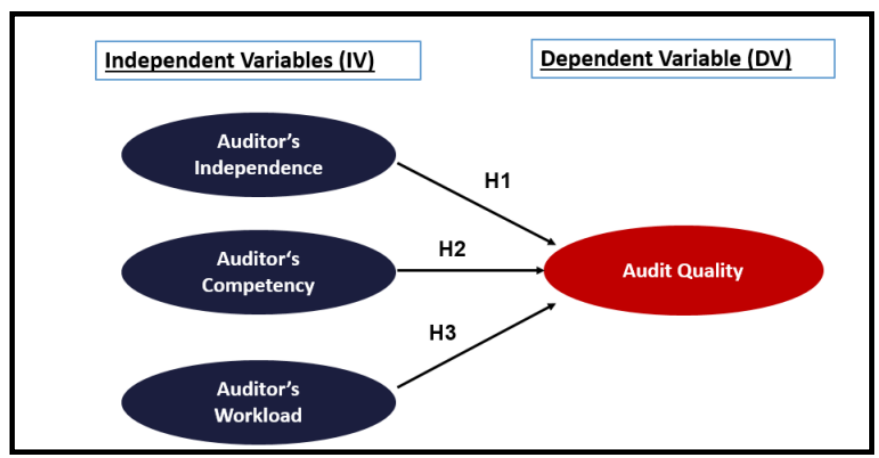

Figure 1. The influence of independence, competency and workload on audit quality of public sector auditors in Malaysia

\section{Research Methodology}

This study is a descriptive and quantitative study, in which it attempted to discover the relationship between independent and dependent variables. The dependent variable in this study was represented by audit quality and the independent variables were represented by auditor's competency, auditor's independence and auditor's workload.

\subsection{Population and Sample of the Study}

The population for this study comprised National Audit Department auditors working with the Federal Government in Putrajaya, Malaysia. The sample respondents in this study were narrowed to auditors assigned to six ministries in Putrajaya that received high operating budget allocations for 2017 and also the headquarters of the National Audit Department. 
This sample had used the purposive sampling method, in which the samples were selected based on the objective of the study. This method was suitable for this study as the purpose of this study was to investigate the relationship between audit quality and auditor's independence, auditor's competency as well as auditor's workload among government auditors.

The auditors assigned to six ministries in Putrajaya that received high operating expenditure budget allocations in 2017 were selected because since the ministries were allocated high budgets, it becomes the duty of auditors to observe whether public funds are managed properly, as expected by the public. It also indicates the auditor's additional workload, which was to verify whether the funds were properly managed as almost all these projects were for the public's benefit. Therefore, the auditors in the selected ministries are appropriate respondents to give input on factors that influence audit quality of the public sector auditors in this study. The level of auditors selected to participate in this study are top management, middle management and support staff from National Audit Department who possessed knowledge, skills, and experience in audit process therefore they are able to provide reliable information needed for this study. The sample size of the study was justified accordance to Bartlett, Kotrlik and Higgins (2001), which indicated that for continuous data with a margin error of 0.03 and an alpha level of 0.05 as well as a population of 600 , the sample size should be approximately 100 respondents.

\subsection{Instrument of the Study}

The instrument used for gathering data is a survey method and this study used a questionnaire for that purpose. According to Sekaran (2016), the questionnaire is a written set of questions that record answers given by respondents and it is the most effective and efficient approach to collect data. The reason for choosing the questionnaire method is to maintain the confidentiality of the information and protect the identity of respondents.

\subsection{Measurement of Variables}

The questionnaires were distributed to 200 public sector auditors working with the Federal Government in Putrajaya. The questionnaires were solicited to the auditors who possessed knowledge about auditing and had participated in the audit process. Each person was targeted and included in this study based on the willingness to participate in the study. The appropriate questions to measure the variables were developed based on arguments from previous literature. The measurement of variables in this questionnaire was based on a 7-point Likert scale, ranging from 'Strongly Disagree -1 to Strongly Agree -7 . The items used in the 7-point Likert Scale were found to be more accurate, easier to use, and gave a better indication of a respondent's true evaluation (Finstad, 2010).

The questionnaire consisted of five sections representing the measurement for each variable. Section A was regarding the demographic information; Section B represented the measurement of auditor's independence; Section $\mathrm{C}$ represented the measurement of auditor's competency; Section D represented the measurement of auditor's workload and the last section represented the measurement of audit quality. Table 1 below shows the summary of previous literature pertaining to measuring the variables involved in this study.

Table 1. Summary of the development of the research instrument

\begin{tabular}{lll}
\hline & Variables of the Study & Source of Reference \\
\hline Dependent Variable: & Audit Quality & Massod and Afzan (2016) \\
\hline Independent Variable: & Auditor's Independence & $\begin{array}{l}\text { Irwansyah et al (2016); Kamuruchi } \\
(2016)\end{array}$ \\
\hline & Auditor's competency & Kamuruchi (2016) \\
\hline & Auditor's workload & M. Nor (2011) \\
\hline
\end{tabular}

The first section (Section A) of the survey instrument is about general information from respondents regarding their demographic profile. The respondents were required to provide some basic information such as gender, age, qualification, current position and years of working experience, which would be useful when performing a descriptive analysis. The second section (Section B) consisted of statements about the auditor's independence according to the perception of government auditors. The appropriate questions regarding auditor's independence was developed based on arguments in previous studies. The questions were modified based on previous literature reviews to suit this study. 
The third section (Section C) represents statements about the auditor's competency from the government auditors' perception. The fourth section (Section D) consists of statements on auditor's workload regarding the perception of government auditors on audit quality in the public sector. Appropriate questions on the auditor's workload were developed based on arguments in previous studies. The questions were modified based on the review of previous literature to suit this study. The last section (Section E) consists of statements on the perception of government auditors on audit quality in the public sector. The relevant questions on audit quality were developed based on previous literature reviews and modified to suit this study.

\subsubsection{Pilot Test}

A pilot test was conducted 2 months before the questionnaires were sent out to selected ministries in Putrajaya. 25 auditors from top management, middle management and support staff from the National Audit Department who possessed knowledge, skills and experience on the audit process were selected to participate in the pilot test. The purpose of the pilot test was to ensure the clarity of the questionnaire to respondents and also to detect other possible weaknesses in the questionnaire. Some feedback received from the pilot study helped to improve the questionnaire, especially to Section B, C and D, where some respondents suggested suitable worded statements for better understanding, from an auditor's perspective.

\subsection{Data Collection and Analysis}

A cover letter was attached to every questionnaire to clarify the objective of the survey and protect the respondent's identity. The researcher's contact number and email address were also attached with the cover letter in case the respondents had any queries about the study. The time given for returning the questionnaire was four weeks from the date of receiving the questionnaire, starting from early August 2017 to early September 2017.

The questionnaires were distributed to respondents through email and online survey, which is an easy access survey platform for respondents and they can answer the questionnaire anytime, anywhere. The email was used as a medium for distributing the questionnaire because in the public sector, email is one of the effective ways of communication and the government auditors usually check their email daily. It is a reliable method for reaching target respondents in a stipulated time. Furthermore, a follow-up email was used to remind respondents before the second week of the set dateline because of a slow response in returning the questionnaires. With the help of the researcher's friends and colleagues, a total of 105 questionnaires were returned from a total of 200 questionnaires distributed that shows a 57\% response rate out of all the questionnaires distributed. The data collected were coded and analysed using both descriptive and inferential statistics. The result was computed using the IBM SPSS version 22 for Windows. Several statistical analyses were carried out for testing the hypotheses. The analysed data are presented in figures and tables, summary statistics of the mean, and standard deviation.

\section{Results and Discussion}

For this study, the public sector auditors working in federal ministries represented the unit of analysis. This section presents the demographic data of respondents comprising questions on gender, age, academic qualification, professional membership, position and years of working in the current workplace. Therefore, statistical data such as frequencies, mean and standard deviation that provides descriptive information were analysed.

\subsection{Demographic Information}

Table 2 shows the detailed results of the demographic profile representing the respondent's gender, age and academic qualification based on Section A in the survey as follows:

Table 2. Demographic profile on gender, age and academic qualification

\begin{tabular}{lllll}
\hline No. & $\begin{array}{l}\text { Demographic Profile } \\
\text { Total All=N }\end{array}$ & & $\begin{array}{l}\text { Frequency } \\
\mathbf{1 1 4}\end{array}$ & $\begin{array}{l}\text { Percentage } \\
\mathbf{1 0 0}\end{array}$ \\
\hline 1. & Gender & Male & 44 & 38.6 \\
\hline & & Female & 70 & 61.4 \\
\hline 2. & Age & 21-30 years old & 9 & 7.9 \\
\hline & & 31-40 years old & 69 & 60.5 \\
\hline & & 41-50 years old & 30 & 26.3 \\
\hline & 51-60 years old & 6 & 5.3 \\
\hline
\end{tabular}




\begin{tabular}{lllll}
\hline 3. & Academic & MCE/SPM/STPM & 5 & 4.4 \\
\hline & Qualification & Diploma & 32 & 28.1 \\
\hline & Bachelor Degree & 74 & 649 \\
\hline & Masters & 3 & 2.6
\end{tabular}

According to the data analysis on gender, it shows that out of 114 respondents, 70 respondents or 61.4 percent of them were female, and 44 respondents or 38.6 percent were male. This shows that both genders were involved in this study. Furthermore, the data analysis on age shows that out of 114 respondents, 69 respondents or 60.5 percent of them were aged between 31 to 40 years old, followed by 30 respondents or 26.3 percent aged between $41-50$ years old, 9 respondents or 7.9 percent aged between 21 to 30 years old and only 6 respondents or 5.3 percent aged 51-60 years old. This implies that participants were well distributed in terms of age.

Next, data analysis on academic qualifications indicated that 74 respondents or 64.9 percent had bachelor's degree qualification, followed by 32 respondents or 28.1 percent with diplomas, 5 respondents or 4.4 percent with MCE/SPM/STPM certificates and only 3 respondents or 2.6 percent with a Master's qualification. This implied that respondents were well educated and were able to respond to research questions with ease.

\subsection{Respondent's Professional Membership, Position and Years of Working in the Current Workplace}

Table 3 demonstrates the detailed results of the respondent's demographic profile such as professional membership, position and years of working in the current workplace based on the Section A in the survey, as follows:

Table 3. Demographic profile on professional membership, position and years of working in current workplace

\begin{tabular}{lllll}
\hline No. & $\begin{array}{l}\text { Demographic Profile } \\
\text { Total All=N }\end{array}$ & & $\begin{array}{l}\text { Frequency } \\
114\end{array}$ & $\begin{array}{l}\text { Percentage } \\
\mathbf{1 0 0}\end{array}$ \\
\hline 1. & Professional & MIA & 21 & 18.4 \\
\hline & Membership & ACCA & 6 & 5.3 \\
\hline & & None of the above & 87 & 76.3 \\
\hline 2. & Position & W29-W36 & 56 & 49.1 \\
\hline & & W41-W44 & 48 & 42.1 \\
\hline & & W48-W54 & 10 & 8.8 \\
\hline 3. & Years of working & 5 years and below & 19 & 16.7 \\
\hline & In current & 6-10 years & 45 & 39.5 \\
\hline & workplace & 11-15 years & 44 & 38.6 \\
\hline & & More than 20 years & 6 & 5.3
\end{tabular}

According to the data analysis on professional membership, it shows that out of 114 respondents, 87 respondents or 76.3 percent had no professional membership, such as MIA or ACCA, only 21 respondents or 18.4 percent had MIA and 6 respondents or 5.3 percent had ACCA memberships.

In addition, the data analysis on position indicates that out of the 114 respondents, 56 respondents or 49.1 percent of them were from W29-W36, followed by 48 respondents or 42.1 percent were from W41-W44 and 10 respondents or 8.8 percent were from W48-W54. This implies that the majority of respondents held a professional position and able to provide reliable information needed for this study.

Furthermore, the data analysis on 'years of working in the current workplace' demonstrated that 45 respondents or 39.5 percent had worked for 6 to 10 years, followed by 44 respondents or 38.6 percent for 11 to 20 years, 19 respondents or 16.7 percent for less than 5 years and only 6 respondents or 5.3 percent for more than 20 years. This implies that the majority of respondents had worked with the organization for a considerable period of time and thus, were in a position to provide credible information needed for this study. 


\subsection{Instrument Validation}

\subsubsection{Reliability Test}

The study uses various statements to gauge the perception of respondents on the four dimensions, namely auditor's independence ( 7 statements), auditor's competency ( 9 statements), auditor's workload ( 7 statements) and audit quality ( 8 statements). The use of statements to measure people's perception of something (dimension) requires that these statements be reliable or consistent. For this, a reliability test was carried out, the summary of the statistics is presented in Table 4 and discussed as follows.

Table 4. Cronbach's Alpha by dimension

\begin{tabular}{lll}
\hline Dimension & No of statements & Cronbach's Alpha \\
\hline 1. Auditor's independence & 7 & 0.609 \\
\hline 2. Auditor's competency & 9 & 0.742 \\
\hline 3. Auditor's workload & 7 & 0.858 \\
\hline 4. Audit quality & 8 & 0.830 \\
\hline
\end{tabular}

An alpha score of above 0.75 generally indicates a scale of high reliability, 0.5 to 0.75 is generally accepted as a moderately reliable scale, while a figure below this is generally a scale of low reliability (Hilton, Brownlow, McMurray and Cozens, 2004). Table 4 presents the Cronbach's alpha values of the four dimensions, ranging from 0.609 (auditor's independence), 0.742 (Auditor's competency), 0.858 (Auditor's workload) and 0.830 (audit quality). The various Cronbach's alpha values above 0.6 indicate that the statements used can reliably measure the perception of respondents on the four dimensions.

\subsubsection{Normality Test}

The analysis to determine a relationship involves the use of significant correlation and regression tests. The appropriate statistical tools for this depend on the normality or non-normality of observation values. A normality test was carried out using the Skewness and Kurtosis value on auditor's independence, auditor's competency, auditor's workload and audit quality. In a normally distributed data, the value of both skewness and kurtosis must be close to zero (Field, 2014). The normality test results show that the skewness and kurtosis value for all the variables are in the range of -1.601 to 1.853 . The value of skewness and kurtosis in the range of -2 to +2 is considered as a normal distribution (Mallery, 2010). This indicates that the mean score for auditor's independence, auditor's competency, auditor's workload and audit quality are normally distributed. Following this conclusion, the study used the parametric statistical tool in the following analysis.

\subsection{Correlation Analysis}

\subsubsection{Relationship Between Auditor's Independence and Audit Quality}

Table 5 shows that the auditor's independence is positively but weakly correlated with audit quality $(r=0.339 ; p<0.01)$. That means that to a small extent, an increase in auditor's independence is associated with an increase in audit quality, and vice versa. The positive relationship result is supported by previous literature (Bouhawia, Irianto and Baridwa, 2015; Sulanjaku and Shngjergji, 2015 and Njoroge, 2016 and Asmara, 2016).

Table 5. Summary statistics of the correlation analysis between audit quality and auditor's independence

\begin{tabular}{lll}
\hline \multirow{2}{*}{ Variable } & Audit Quality & \\
\cline { 2 - 3 } & Pearson Coefficient of Correlation $(r)$ & $p$-value \\
\hline Auditor's Independence & 0.339 & $0.000^{* *}$ \\
\hline
\end{tabular}

** Significant at 0.01

\subsubsection{Relationship Between Auditor's Competency and Audit Quality}

Table 6 shows that auditor's competency is positively and highly correlated with audit quality $(r=0.714 ; p<0.01)$. The positive relationship result is supported by previous studies (Suyono, 2012; Irmawan, Hudaib, and Haniffa, 2013 and 
Octavia and Widodo, 2015). The result implies that higher auditor competency will improve audit quality, and vice versa.

Table 6. Summary statistics of correlation analysis between audit quality and auditor's competency

\begin{tabular}{lll}
\hline \multirow{2}{*}{ Variable } & Audit Quality & \\
\cline { 2 - 3 } & Pearson Coefficient of Correlation $(r)$ & $p$-value \\
\hline Auditor Competency & 0.714 & $0.000 * *$ \\
\hline Significant at 0.01 & &
\end{tabular}

\subsubsection{Relationship Between Auditor's Workload and Audit Quality}

Table 7 shows a negative but insignificant correlation between auditor's workload and audit quality $(p>0.05)$. The result implies there is no significant correlation between auditor's workload and audit quality. However, the negative relationship is supported by previous studies (Persellin et al., 2017 and Lopez and Peter, 2012). The negative relationship indicates that as auditor's workload increases, the auditors will feel more job strain and less job satisfaction. Thus, the strain felt by auditors will likely impair the audit quality.

Table 7. Summary statistics of correlation analysis between audit quality and auditor's workload

\begin{tabular}{lll}
\hline \multirow{2}{*}{ Variable } & Audit Quality & \\
\cline { 2 - 3 } & Pearson Coefficient of Correlation $(r)$ & $p$-value \\
\hline Auditor's Workload & -0.077 & 0.416 \\
\hline
\end{tabular}

\subsection{Regression Analysis}

Multiple linear regression is a statistical technique that uses several explanatory variables to predict the outcome of a response variable. The goal of multiple linear regression is to model the relationship between the explanatory and response variables. As a predictive analysis, the multiple linear regression is used to explain the relationship between one continuous dependent variable from two or more independent variables.

Table 8 shows the summary of the multiple linear regression model and overall fit statistics. From the $\mathrm{R}^{2}$ results, it shows that $55.0 \%$ of the variation in Audit Quality is explained by the variation in auditor's independence, auditor's competency and auditor's workload. The adjusted R-squared compares the explanatory power of regression models that contain different numbers of predictors. Also, from the adjusted $\mathrm{R}^{2}$, it indicates that $53.8 \%$ of the variation in Audit Quality is explained by the variation in auditor's independence, auditor's competency and auditor's workload, taking into account the sample size and number of independent variables. Hence, the effect of auditor's independence, auditor's competency and auditor's workload as a whole on audit quality is moderately high.

On another note, the F-test is used to determine the overall significance of the model and it shows that if there is a linear relationship between all the independent variables (IV) considered together with the dependent variable (DV). The F-test has the null hypothesis that there is no linear relationship between the variables (in other words $\mathrm{R}^{2}=0$ ). If the F-test is highly significant, thus it can be assumed that there is a linear relationship between the variables in the model. Since the F-test statistics were in the rejection region ( $\mathrm{p}$-value $=.000<.01$ at .01 significance level), therefore this study rejected $\mathrm{H}_{0}$, and concluded that there is evidence that at least one independent variable affects audit quality. Thus, this model is significant as it shows if there is a linear relationship between auditor's independence, auditor's competency and auditor's workload. It is proven, as the auditor's independence p-value $=.008<.01$, that there is evidence that auditor's independence and auditor's competency affect audit quality at a .01 significance level $(\alpha=.01)$. In addition, according to Table 8 , auditor's workload with a p-value $=.399>.05$ significance level $(\alpha=.05$. $)$ indicates that there is evidence that auditor's workload does not significantly affect the audit quality. Next, the study found a relationship between the coefficient of auditor's independence (0.183) and auditor's competency (0.677), meaning that an increase in auditor's independence and competency increases audit quality, however changes in auditor's workload has no impact on audit quality. 
Table 8. Estimated regression equation

\begin{tabular}{llll}
\hline Variable & Coefficient & $\boldsymbol{t}$-value & $\boldsymbol{p}$-value \\
\hline Auditor's Independence & 0.183 & 2.723 & $0.008^{*}$ \\
\hline Auditor's Competency & 0.677 & 10.312 & $0.000^{* *}$ \\
\hline Auditor's Workload & -0.056 & -0.847 & 0.399 \\
\hline $\mathrm{F}$ & 44.787 & & $0.000^{* *}$ \\
\hline $\mathrm{R}^{2}$ & 0.550 & &
\end{tabular}

* significant at 5\% level (2-tailed), ** significant at $1 \%$ level (2-tailed)

The purpose of this study was to examine the relationship between factors that might influence the audit quality of public sector auditors. Therefore, the coefficient regression analysis was used to justify the hypotheses of the study. All the results of the variables are explained, as shown in Table 9.

Table 9. Summary of the hypotheses results

\begin{tabular}{llll}
\hline NO. & IV & HYPOTHESES STATEMENT & RESULTS \\
\hline $\mathrm{H}_{1}:$ & $\begin{array}{l}\text { Auditor's } \\
\text { Independence }\end{array}$ & $\begin{array}{l}\text { There is a positive relationship between } \\
\text { Auditor's Independence and Audit } \\
\text { Quality. }\end{array}$ & $\begin{array}{l}\text { There is a significant positive relationship } \\
\text { between Auditor's Independence and Audit } \\
\text { Quality as p-value }=.008<.05(\alpha=.01) .\end{array}$ \\
\hline $\mathrm{H}_{2}:$ & $\begin{array}{l}\text { Auditor's } \\
\text { Competency }\end{array}$ & $\begin{array}{l}\text { There is a positive relationship between } \\
\text { Auditor's Competency and Audit } \\
\text { Quality. }\end{array}$ & $\begin{array}{l}\text { There is a significant positive relationship } \\
\text { between Auditor's Competency and Audit } \\
\text { Quality as p-value }=.000<0.001(\alpha=.01) .\end{array}$ \\
\hline $\mathrm{H}_{3}:$ & $\begin{array}{l}\text { Auditor's } \\
\text { Workload }\end{array}$ & $\begin{array}{l}\text { There is a negative relationship between } \\
\text { Auditor's Workload and Audit Quality. }\end{array}$ & $\begin{array}{l}\text { There is a insignificant negative relationship } \\
\text { between Auditor's Workload and Audit Quality } \\
\text { as p-value }=.399>.05(\alpha=.05) .\end{array}$ \\
\end{tabular}

\section{Summary of the Findings}

This research study explored the factors that influence audit quality from the perspective of public sector auditors in Malaysia. The study predicts that auditor's independence and auditor's competency have a positive influence on audit quality but the auditor's workload has a negative influence on audit quality. The Theory of Inspired Confidence was applied to test the relationship and association between the three variables. The theory suggests that the ability to find misstatements in the clients' accounting system uses auditor's competency and independence. The auditors must be independent when reporting any breach or error in the client's organizations that might indicate audit quality so that to gain the confidence of the users of financial statements. Therefore, improving audit quality is perceived to be the main factor for incumbent auditors when enhancing public confidence towards their profession. Thus, maintaining independence and competency is the cornerstone for auditors when providing reasonable assurance of audit quality.

The first objective of this study was to examine the positive relationship between auditor's independence and audit quality. The results showed that there was a significant and positive relationship between auditor's independence and audit quality, which was in line with previous studies (Suyono, 2012; Irmawan et al., 2013; Octavia and Widodo, 2015). The results confirmed that auditor independence might influence audit quality. Audit quality would improve when the auditor is more independent. This means when an auditor is independent, the auditor would be able to present a true and fair audit report, which would make the financial statement credible and reliable (Olagunju and Adebayo, 2011). When an auditor is more independent, the audit quality will increase and therefore inspire confidence in the public regarding the reliability of the financial statement (Suyono, 2012). Moreover, when the auditor is independent, the likelihood of discovering detailed misstatements would be greater and might improve audit quality (Octavia and Widodo, 2015).

The second objective of the study was to confirm the relationship between auditor's competency and audit quality. In this study, the second hypothesis was also supported, which was in line with the previous literature (Hadisantoso et al., 2017; Asmara, 2016). Competency of an auditor might differ from one auditor to another. It is a subjective matter 
and is influenced by various factors. Auditor competency is imperative in promoting good governance and guaranteeing effective use of public resources (Njoroge 2016). Thus, in this study, the findings indicated that the more competent the auditor, the better the audit quality. Njoroge (2016) supported the notion that auditors with high competency levels have a positive connection with performance, which leads to more compelling corporate administration.

The findings also indicated that auditor's workload seems to have no significant impact on audit quality. The last objective was to examine the relationship between auditor's workload and audit quality. The results were supported by Mohd Nor (2011), who found that workload did not have a critical impact on audit quality. Notwithstanding that, this outcome proposed that management might need to improve the positive outcome of workload, keeping workload sensibly high to keep up with its inspiring impact while minimizing the dysfunctional effects.

The overall findings indicated that auditor's independence and auditor's competency had met the expectations of the research objectives and hypotheses. The results provided evidence that auditor's independence and auditor's competency had significant influence on audit quality in Malaysian public sector auditors. This might be because when auditors are independent, they are unrestricted and unbiased in providing a true and fair view of the financial statements. Hence, the auditors will perform a better-quality audit. In addition, when the auditors are more competent, they have wider knowledge and experience to perform a more quality audit and provide substantiated opinions on financial statements. Consequently, it confirms the underpinning Theory of Inspired Confidence in audit quality literature, which indicates that the more independent and competent the auditors, the better the audit quality; therefore, the users gain confidence in the financial statement and audit reports.

However, based on the findings, auditor's workload did not have a significant impact on audit quality. It is a good sign because this indicates that despite having lots of audit work; the auditors still maintained a good audit quality. The public need not be worried of the heavy load burden on auditors as they will still uphold their quality of work in auditing financial statements.

\subsection{Research Implications, Limitations and Future Research}

The findings of this study indicate that auditor's competency has been proved to be one of the contributing factors to audit quality. Hence, according to the results in this study, a better quality of public audit performance appears to indirectly contribute to desirable outcomes for the public. Auditing agencies ought to highlight the importance of auditor's competency and auditor's independence in enhancing audit quality. Auditor's knowledge, skills and expertise among public auditors are constructive competencies that generate good quality public sector audits.

Ultimately, public sector auditing can strengthen public governance by providing accountable reports as well as protect the core values of the public sector entity. Hence, this can ensure that managers and public officers' conduct the public's business in a transparent, fair, and honest manner as well as with high integrity. Hence, appointing competent auditors to serve at all levels of the public sector audit should effectively support the agenda for better audit quality. Therefore, the public might obtain benefits from this as government entities and departments are more transparent and able to serve the public more efficiently.

Whilst this study might have provided empirical contributions in numerous aspects; thus, like any research, it is subject to certain limitations. Although the research had achieved its aims, there were some unavoidable limitations. First, due to the limited time given to complete this study, which was within four months, the sample size was small and comprised public sector auditors working only in the Putrajaya area. The involvement of this group was constrained by practical issues concerning access to individuals and time availability. Therefore, to generalize these results in order to cover a larger population would be inadequate. Hence, future research should attempt to expand the sample size of individual participants, possibly through wider survey methods and include public auditors from other branches and offices in Malaysia.

This study only examined the effect of auditor's independence, auditor's workload and auditor's competency on audit quality. However, there are other variables that could be investigated by future studies such as effect of auditor's personality, ethical values of the auditors or the workplace environment on audit quality. Hence, the findings might contribute to a better understanding of the factors that affect audit quality.

\section{References}

ACFE. (2016). Report to the Nations on Occupational Fraud and Abuse 2016 Global Fraud Study. Retrieved from https://www.acfe.com/rttn2016/docs/2016-report-to-the-nations.pdf

Adeyemi, S. B., Okpala, O., \& Dabor, E. L. (2012). Factors Affecting Audit Quality in Nigeria. International Journal of Business and Social Science, 3(20), 198-209. 
Ahmad, N. H., Othman, R., Othman, R., \& Jusoff, K. (2009). The effectiveness of internal audit in Malaysian public sector. Journal of Modern Accounting and Auditing, 5(9), 53-62.

Ali, A. M. (2016). 1MDB: The Auditor General Office's Questions. Journal of Public Administration and Governance, 6(1), 50-72. https://doi.org/10.5296/jpag.v6i1.9056

Alireza Eskandari, A., Abdul Rasid, S. Z., Basiruddin, R., \& Hosseini, M. R. (2014). Review of Empirical Literature on Audit Quality and Cost of Debt Capital. International Journal of Accounting and Taxation December, 2(4), 81-92. https://doi.org/10.15640/ijat.v2n4a5

Al-Khaddash, H., Al-Nawas, R., \& Ramadan, A. (2013). Factors affecting the quality of Auditing: The Case of Jordanian Commercial Banks. International Journal of Business and Social Science, 4(11), 206-222.

Asmara, R. Y. (2016). Effect Of Competence And Motivation Of Auditors Of The Quality Of Audit: Survey On The External Auditor Registered Public Accounting Firm In Jakarta In Indonesia. European Journal of Accounting, Auditing and Finance Research, 4(1), 43-76.

Bouhawia, M. S., Irianto, G., \& Baridwan, Z. (2015). The Effect of Working Experience, Integrity, Competence, and Organizational Commitment on Audit Quality (Survey State Owned Companies in Libya). Journal of Economics and Finance, 6(4), 60-67.

Brown, R. E. (2005). Enron/Andersen: crisis in U.S. accounting and lessons for government. Retrieved from https://www.researchgate.net/publication/228266414_EnronAndersen_Crisis_in_US_Accounting_and_Lessons _for_Goverment

Carslaw, C., Pippin, S., \& Mason, R. (2012). Are public sector auditors more effective than private sector audit firms when auditing governmental entities? Some evidence from United States. Public and Municipal Finance, 1(1), 49-57.

Chee, K. L., \& Ki, W. O., (2016). A case study on fraudulent financial reporting: evidence from Malaysia. Accounting Research Journal, 29(1), 4-19. https://doi.org/10.1108/ARJ-11-2013-0084

Chia, K.W., Tan, G. M., Ter, S. Y., Toh, S. Y., \& Yap, Y. M. (2013). The Relationship between Work Stress and Auditors' Job Performance. Retrieved from http://eprints.utar.edu.my/1017/1/AC-2013-09ABB03183-1.pdf

DeAngelo, L. (1981). Auditor size and audit quality. Journal of Accounting and Economics, 3(3), 189-199.

Enofe, A. O., Mgbame, C., Aderin, A., \& Ehi-Oshio, O. U. (2013). Determinants of Audit Quality in the Nigerian Business Environment. Research Journal of Finance and Accounting, 4(4), 36-43.

Hadisantoso, E., Sudarma, I. M., \& YohanisRura (2017). The Influence of Professionalism and Competence of Auditors towards the Performance of Auditors. Scientific Research Journal, V(I),10-14.

Hosseinniakani, S. M., \& Mota, H. I. R. (2014). Review on Audit Quality Factors. International Journal of Academic Research in Accounting, Finance and Management Sciences, 4(2), 243-254.

Irmawan, Y., Hudaib, M., \& Haniffa, R. (2013). Exploring the perceptions of auditor independence in Indonesia. Journal of Islamic Accounting and Business Research, 4(2), 173-202. https://doi.org/10.1108/JIABR-09-2012-0061

Kitata, S. (2016). Factors affecting quality of External Auditing: The case of Ethiopian Commercial Banks. Retrieved from http://etd.aau.edu.et/bitstream/123456789/9866/1/Solomon\%20Kitata.pdf

Krishnan, L. (2011). Legal Issues on the Scandals Involving Auditors. Retrieved from https://www.econbiz.de/Record/legal-issues-on-the-scandals-involving-auditors-loganathan-krishnan-author-em ail-loganathan-utar-edu/10010535911

Lee, S. C., Su, J. M., Tsai, S. B., Lu, T. L., \& Dong, W. W. (2016). A comprehensive survey of government auditors' self-efficacy and professional development for improving audit quality. https://doi.org/10.1186/s40064-016-2903-0

Lopez, D. M., \& Peters, G. F. (2012). The Effect of Workload Compression on Audit Quality. Auditing: A Journal of Practice \& Theory, 31(4), 139-165. https://doi.org/10.2308/ajpt-10305

Mahdi, T. M. (2013). Factors Affecting the Quality of the Auditing Work in Public Sector. Indian Journal of Applied Research, 3(6), 1-6. https://doi.org/10.15373/2249555X/JUNE2013/1

Marsel Sulanjaku, M., \& Ali Shingjergji, A. (2015). An Overview of Factors Affecting Auditing Quality in Albania. Academic Journal of Interdisciplinary Studies, 4(3), 223-228. https://doi.org/10.5901/ajis.2015.v4n3s1p223 
Masood, A., \& Afzal, M. (2016). Determinants of Audit Quality in Pakistan. Journal of Quality and Technology Management, XII(II), 25-49.

Massod, A., \& Lodhi, R. N. (2015). Factor affecting the success of government audit. Case study of Pakistan. Universal Journal of Management, 3(2), 52-62.

Mohd Nor, M. (2011). Auditor Stress: Antecedents and relationships to audit quality. Retrieved from http://ro.ecu.edu.au/theses/403/

Octavia, E., \& Widodo, N. R. (2015). The Effect of Competence and Independence of Auditors on the Audit Quality. Research Journal of Finance and Accounting, 6(3), 189-194. Retrieved from http://www.iiste.org/Journals/index.php/RJFA/article/view/19959

Othman, R., Nath, N., \& Mahzan, N. (2013). Public Sector Audit: A Century and Beyond- the Case of Malaysia. Retrieved from http://repository.um.edu.my/33955/

Persellin, J. S., Schmidt, J. J., Vandervelde, S., \& Wilkins, M. S. (2017). Survey Evidence on the Relationship between Audit Workloads, Job Satisfaction and Audit Quality. Retrieved from https://papers.ssrn.com/sol3/papers.cfm?abstract_id=2534492\&rec=1\&srcabs=2532494\&alg=1\&pos=7

Persellin, J. S., Schmidt, J. J., Vandervelde, S., \& Wilkins, M. S. (2014). Auditor Perceptions of Audit Workloads, Audit Quality, and the Auditing Profession. https://doi.org/10.2139/ssrn.2534492

Phan, T. H. (2016). The Research of Factors Affecting the Quality of Audit Activities: Empirical Evidence in Vietnam. International Journal of Business and Management, 11(3), 83-94. https://doi.org/10.5539/ijbm.v11n3p83

Samaila, M., Uzochukwu, O. C., \& Ishaq, M. (2018). Organizational Politics and Workplace Conflict in Selected Tertiary Institutions in Edo State, Nigeria. International Journal of Emerging Trends in Social Sciences, 4(1), 26-41. https://doi.org/10.20448/2001.41.26.41

Samelson, D., Lowensohn, S., \& Johnson, L. E. (2006). The Determinants of Perceived Audit Quality and Auditee Satisfaction in Local Government. Journal of Public Budgeting, Accounting \& Financial Management, 18(2), 139-166. https://doi.org/10.1108/JPBAFM-18-02-2006-B001

Senathip, T., Mujtaba, B. G., \& Cavico, F. J. (2017). Policy-Making Considerations for Ethical and Sustainable Economic Development. Economy, 4(1), 7-14. https://doi.org/10.20448/journal.502.2017.41.7.14

Setiyawati, H., Iskandar, D., \& Basar, Y. S. (2018). The Quality of Financial Reporting through Increasing the Competence of Internal Accountants and Accrual Basis. International Journal of Economics, Business and Management Studies, 5(1), 31-40. https://doi.org/10.20448/802.51.31.39

Stavrou, P. D. (2018). Psychoanalytic Psychotherapy as a Treatment for Depression in Adolescents: A Case Study. Global Journal of Social Sciences Studies, 4(2), 91-101. https://doi.org/10.20448/807.4.2.91.101

Stübinger, J., Walter, D., \& Knoll, J. (2017). Financial market predictions with Factorization Machines: Trading the opening hour based on overnight social media data (No. 19/2017). FAU Discussion Papers in Economics.

Sulaiman, N. A. (2011). Audit Quality in Practice: A Study of Perceptions of Auditors, Audit Committee Members and Quality Inspectors. Retrieved from https://www.escholar.manchester.ac.uk/uk-ac-man-scw:129909

Supian, K., \& Ab, N. (2018). The Role of Supplier, Top Management and Government in Halal Practices Integrity of Malaysian Food Business. International Journal of Asian Social Science, 8(8), 549-559. https://doi.org/10.18488/journal.1.2018.88.549.559

Suyono, E. (2012). Determinant Factors Affecting the Audit Quality: An Indonesian Perspective. Global Review of Accounting and Finance, 3(2), 42-57.

Titus, M., Muturi, W., \& Kabiru, J. (2014). Factors Affecting External Auditors' Independence in Discharging Their Responsibilities: A Survey of Medium Level Auditing Firms in Nairobi. International Journal of Business \& Law Research, 2(4), 22-35.

Uma, S., \& Roger, B. (2016). Research Methods for Business (7th ed.). United Kingdom: John Wiley \& Sons Ltd.

Usman, A., Sudarma, M., Habbe, H., \& Said, D. (2014). Effect of Competence Factor, Independence and Attitude against Professional Auditor Audit Quality Improve Performance in Inspectorate (Inspectorate Empirical Study in South Sulawesi Province). Journal of Business and Management, 16(1), 1-13. https://doi.org/10.9790/487X-16120113 